\title{
Biosaintifika
}

Journal of Biology \& Biology Education

http://journal.unnes.ac.id/nju/index.php/biosaintifika

\section{Morphological Diversity of Local Sorghum Cultivar (Sorghum bicolor) of East Nusa Tenggara, Indonesia}

\author{
Ite Morina Yostianti Tnunay ${ }^{1},{ }^{\varpi}$ Tatik Chikmawati $^{2}$, Miftahudin $^{2}$ \\ DOI: http://dx.doi.org/10.15294/biosaintifika.v11i1.15199 \\ ${ }^{1}$ Plant Biology Graduate Program, Department of Biology, Faculty of Mathematics and Natural Sciences, \\ Institut Pertanian Bogor, Indonesia \\ ${ }^{2}$ Department of Biology, Faculty of Mathematics and Natural Sciences, Institut Pertanian Bogor, Indonesia
}

\section{History Article}

Received 27 July 2018 Approved 13 February 2019 Published 30 April 2019

\section{Keywords}

Coefficient Similarity; East Nusa Tenggara; Genetic Diversity; Local Cultivar

\begin{abstract}
Sorghum has great potential to be developed in marginal lands of Indonesia including East Nusa Tenggara. However, the information about sorghum diversity in this area was very limited. This research aimed to describe morphological variation, and assessing the value of genetic diversity based on morphological characters of local sorghum cultivar of East Nusa Tenggara. The exploration and sample collection were conducted in 3 islands, i.e.: Timor, Sumba, and Flores. The observation of morphological characters was based on sorghum descriptor. Morphological character similarities were analyzed using Simple Matching (SM) coefficient, and a dendrogram was constructed using Unweighted Pair Group Method with Arithmetic Average (UPGMA) method. The results showed that 36 accessions of sorghum in East Nusa Tenggara varied in 17 morphological characters. At the similarity coefficients of $48 \%$, all sorghum accessions were separated into 2 groups based on the presence or absence of aleurone layer. Group I consisted of 12 accessions with no aleurone layer, while group II consisted of 24 accessions has aleurone layer. The genetic diversity of sorghum of East Nusa Tenggara is low $(\mathrm{I}=0.62-0.71$ and $\mathrm{h}=0.37$ $0.42)$. The genetic diversity between populations $\left(\mathrm{H}_{\mathrm{T}}=0.4203\right)$ is higher than within populations $\left(\mathrm{H}_{\mathrm{s}}=0.3961\right)$. This study provides the first complete information about sorghum diversity in East Nusa Tenggara that will be useful as basic information for sorghum development in this area in the future.
\end{abstract}

\section{How to Cite}

Tnunay, I. M. Y., Chikmawati, T., \& Miftahudin. (2019). Morphological Diversity of Local Sorghum Cultivar (Sorghum bicolor) of East Nusa Tenggara, Indonesia. Biosaintifika: Journal of Biology \& Biology Education, 11(1), 47-54.

\footnotetext{
$\triangle$ Correspondence Author:
}

J1. Raya Dramaga, Babakan, Dramaga, Bogor, Jawa Barat 16680

E-mail: tchikmawati@yahoo.com
p-ISSN 2085-191X e-ISSN 2338-7610 


\section{INTRODUCTION}

Sorghum is the fifth important cereal crop in the world after wheat, rice, corn, and barley that is used mostly for food, feed, industry, and energy source (Dahlberg et al., 2011). Physiologically, sorghum has wide adaptability to abiotic stress, and able to grow well on marginal land such as dry land (Dahlberg et al., 2011).

Over the last 50 years, sorghum development has been increased in the world, and the United States is the largest sorghum producer (Etuk et al., 2012). Many improved sorghum cultivars have also been released in Asia including Indonesia. Indonesia has released 13 improved sorghum cultivars, 2 pure lines selected from local landraces and the others are from direct introductions (Deb et al., 2004). The development of sorghum in Indonesia is now rising to support the food diversification program. Sorghum becomes one of non-rice food which has been developed on many dry areas in Indonesia included in East Nusa Tenggara (Sirappa, 2003).

Sorghum developed in East Nusa Tenggara consisted of many diverse local cultivars, but their diversity had not been described and documented yet. The diversity of local cultivar of sorghum showed high genetic diversity (Morojele \& Mbewe, 2015), unfortunately, the information was still unavailable. Information of genetic diversity is important for improvement, conservation, and survival of sorghum (Gerrano et al., 2014; Amelework et al., 2016). Previous studies reported that based on morphological character, the genetic diversity of sorghum in North Shewa and South Welo Ethiopia is high ( 0.32-0.98) (Abdi et al., 2002). Morphological character is more practice and easy to be observed when it is used for genetic diversity analysis (Gerrano et al., 2014). The selected morphological characters should be a qualitative character because it is relatively stable from environment influence. The aims of this study were to (1) describe the variation of sorghum morphology of local cultivars in East Nusa Tenggara, (2) analyze the relationships between, and (3) assess the genetic diversity of local cultivars of East Nusa Tenggara based on their morphological characters.

\section{METHOD}

\section{Plant Materials}

A total of 36 accessions of local sorghum cultivars were collected from 11 districts in three islands (Figure 1), i.e. Timor (Kupang, North Central Timor, South Central Timor and Belu districts), Sumba (East and Southwest Sumba districts), and Flores (East Flores, Sikka, Ende, Nagekeo, and Ngada districts) with the diverse local names (Table 1). The seeds of each local cultivar was collected and the name was given based on the district name and collection number. A local cultivar of one location was treated as an accession. All accessions then were grown in a greenhouse of Bogor Agricultural University.

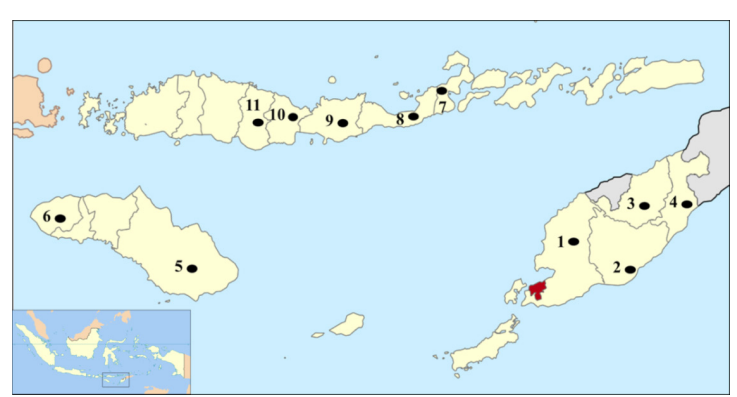

Figure 1. Location map for exploration and sample collection. $1=$ Kupang, $2=$ South Central Timor, $3=$ North Central Timor, $4=$ Belu, $5=$ East Sumba, 6=Southwest Sumba, 7=East Flores, $8=$ Sikka, $9=$ Ende, $10=$ Nagekeo, $11=$ Ngada .

\section{Sorghum Planting}

Each accession of sorghum was planted in a $30 \times 30 \mathrm{~cm}$ polybag with 5 replications and 2 plants on each polybag. The polybags was placed randomly. Fertilization was given twice, on the $30^{\text {th }}$ and $60^{\text {th }}$ day after planting. Pest and disease control were conducted using standard practices. The sorghum flowers were encased before the pollen riped to prevent cross-breeding between accessions.

\section{Observation of Morphological Characters}

As many as 20 morphological characters of generative organ were observed. The observed characters were adapted from sorghum descriptor (IBPGR \& ICRISAT 1993), i.e. inflorescence (panicle) compactness, panicle shape, panicle stands; shape, base and apex bracts color of seed with bracts (glume), presence and location of pubescent on bracts, angle on palea, awn presence, and percentage of seed covered by bracts; shape, base and apex color of seed without bracts (grain), seed lustre, seed dimple, aleuron presence and color, endosperm color, and endosperm texture.

\section{Data Analysis}

The morphological characters were used for phenetic and genetic diversity analysis. The selected morphological characters were arranged in a matrix data and then scored. The sorghum 
Ite Morina Yostianti Tnunay et al. / Biosaintifika 11 (1) (2019) 47-54

Table 1. Identities and local names of 36 accessions of sorghum of East Nusa Tenggara

\begin{tabular}{lll}
\hline Island & District & Accession code \\
\hline Timor & Kupang & Pen mina 1, pen mina 2, pen mina 3, pen mina 4 \\
& South Central Timor & Buka 1, buka 2 \\
& North Central Timor & Sain 1 \\
& Belu & Batar ainaruk 1, batar ainaruk 2, batar ainaruk 3, batar ainaruk 4 \\
Sumba & East Sumba & Watar 1 \\
& Southwest Sumba & Watar pia 1, watar pia 2 \\
Flores & East Flores & Watar holo 1, watar holo 2, watar holo 3, wara blong mera 1, watar nae \\
& & eke 1, riang kemie 1, riang kemie 2, watar holo 4, watar holo 5 \\
& Sikka & Watar 2, watar 3, watar 4, watar 5, watar 6 \\
& Ende & Lolo 1, lolo 2, lolo 3 \\
& Nagekeo & Latung 1, rolo 1, olo wolo viki 1, olo wolo 1 \\
& Ngada & Sae lewa 1 \\
\hline
\end{tabular}

phenetic was analyzed using Simple Matching (SM) similarity index and a dendrogram was constructed using Unweighted Pair Group Method with Arithmatic Average (UPGMA) method. Phenetic analysis were performed with Numerical Taxonomy and Multivariate Analysis System (NTSys) software version 2.11a (Rohlf, 2001). Population Genetic Analysis (Popgene) version 32 (Yeh et al., 1999) software was used to analyze ten genetic diversity parameters: number of observed alleles $(\mathrm{Na})$, number of effective alleles $(\mathrm{Ne})$, genetic diversity (h), Shannon's Information Index (I), number of polymorphic loci, percentage of polymorphic loci, genetic diversity between population $\left(\mathrm{H}_{\mathrm{T}}\right)$, genetic diversity within population $\left(\mathrm{H}_{\mathrm{S}}\right)$, genetic differentiation between population $\left(\mathrm{G}_{\mathrm{ST}}\right)$, and gene flow $(\mathrm{Nm})$.

\section{RESULT AND DISCUSSION}

Diversity of Morphological Characters of Local Sorghum Cultivar from East Nusa Tenggara

A total of 20 generative characters were observed in 36 sorghum accessions. Based on the overall characters observed, 17 characters are varied, while 3 characters are not. All accessions have the same vertical stems, ellipse panicles, and white (FFFFFF) endosperm. The variation characters of sorghum can be seen in Table 2. The variations have association with inflorescence (panicle) compactness, shape of seed with bracts, base and apex bracts color, location of pubescent on bracts, angle on palea, percentage of seed covered by bracts; shape, base and apex color of seed without bracts, seed lustre, seed dimple, aleurone color, and endosperm texture (Figure 2 and 3 ). The presence of pubescent on bracts, angle on palea, awn on seeds, seed dimple and aleurone layer were found in some accessions.

Most sorghum of East Nusa Tenggara are characterized by open branches, oval-shaped seed, black base and apex bracts, pubescent on bracts, with no angle on palea, no awn on seed apex, $100 \%$ seed covered by bracts, brown base and apex of seed without bracts, no seed dimple, dull seed, with dark brown aleurone, and intermediate endosperm texture.

\section{The relationships of Sorghum Local Cultivars in East Nusa Tenggara}

Phenetic analysis of 36 sorghum accessions of East Nusa Tenggara were done based on 17 morphological characters which were qualitative and constant characters. All accessions were groupped into one large group with a similarity coefficient of $45 \%$ (Figure 4). In similarity coefficient of $48 \%$, all sorghum accessions were separated into 2 groups based on the presence or absence of aleurone layer. Group I consisted of 12 accessions without aleurone layer, while group II consisted of 24 accessions with aleurone layer. The analysis also classified some accessions that have similar characters in the percentage of seed covering by bracts and the color of bracts apex. In addition, there are similar accessions with similarity coefficient about $100 \%$. It means that, some accessions which have same morphological characters also spreaded on other islands, but they have different local names.

All accessions in group I do not have aleurone layer in the seed, but they have semi-open branches and open inflorescence branches, rounded and oval shape of seed with bracts, goldenrod, goldenrod with black pattern, orange, brown, red, maroon, and black of base and apex bracts color. 
Ite Morina Yostianti Tnunay et al. / Biosaintifika 11 (1) (2019) 47-54

Table 2. Variation character of local sorghum cultivar of East Nusa Tenggara

\begin{tabular}{|c|c|}
\hline Characters & Characters states (the percentage of character states) \\
\hline Inflorescence (panicle) compactness & $\begin{array}{l}\text { compact }(22 \%) \text {, semi-compact }(3 \%) \text {, semi-open branches } \\
(3 \%) \text {, open branches }(72 \%)\end{array}$ \\
\hline Shape of seed with bracts & rounded $(3 \%)$, oval $(83 \%)$, ellipse $(14 \%)$ \\
\hline Base bracts color & $\begin{array}{l}\text { goldenrod (DAA520) }(17 \%) \text {, goldenrod with black pattern } \\
\text { (DAA520+000000), }(6 \%) \text {, brown (D2691E) }(22 \%) \text {, orange } \\
\text { red }(\mathrm{FF} 4500)(3 \%) \text {, red (FF0000) }(8 \%) \text {, maroon }(800000) \\
(3 \%) \text {, black }(000000)(41 \%)\end{array}$ \\
\hline Apex bracts color & $\begin{array}{l}\text { goldenrod }(17 \%) \text {, goldenrod with black pattern }(6 \%) \text {, or- } \\
\text { ange }(\text { FFA } 500)(6 \%) \text {, brown }(19 \%) \text {, red }(8 \%) \text {, maroon }(3 \%) \text {, } \\
\text { black }(41 \%)\end{array}$ \\
\hline Presence of pubescent on bracts & absent $(17 \%)$, present $(83 \%)$ \\
\hline Location of pubescent on bracts & only on edge ( $40 \%)$, on edge and apex $(60 \%)$ \\
\hline Presence of angle on palea & absent $(17 \%)$, present $(83 \%)$ \\
\hline Presence of awn & absent $(97 \%)$, present $(3 \%)$ \\
\hline Percentage of seed covered by bracts & $25 \%(6 \%), 50 \%(27 \%), 75 \%(17 \%)$, and $100 \%(50 \%)$ \\
\hline Shape of seed without bracts & round $(6 \%)$, oval $(94 \%)$ \\
\hline Base color of seed without bracts & $\begin{array}{l}\text { white }(39 \%) \text {, brown }(55 \%) \text {, dark brown }(8 B 4513)(3 \%) \text {, bur- } \\
\text { ly wood (DEB887) }(3 \%)\end{array}$ \\
\hline Apex color of seed without bracts & $\begin{array}{l}\text { white }(39 \%) \text {, white brown (FFDEAD) }(3 \%) \text {, brown }(41 \%) \text {, } \\
\text { dark brown }(14 \%) \text {, burly wood }(3 \%)\end{array}$ \\
\hline Seed dimple & absent $(97 \%)$, present $(3 \%)$ \\
\hline Seed lustre & dull (94\%), lustre (6\%) \\
\hline Presence of aleurone & absent $(33 \%)$, present $(67 \%)$ \\
\hline Aleurone color & dark brown (96\%), sienna (A0522D) (4\%) \\
\hline Endosperm texture & $\begin{array}{l}\text { corneus dominant }(8 \%) \text {, intermediate }(42 \%) \text {, starch domi- } \\
\text { nant }(50 \%)\end{array}$ \\
\hline
\end{tabular}

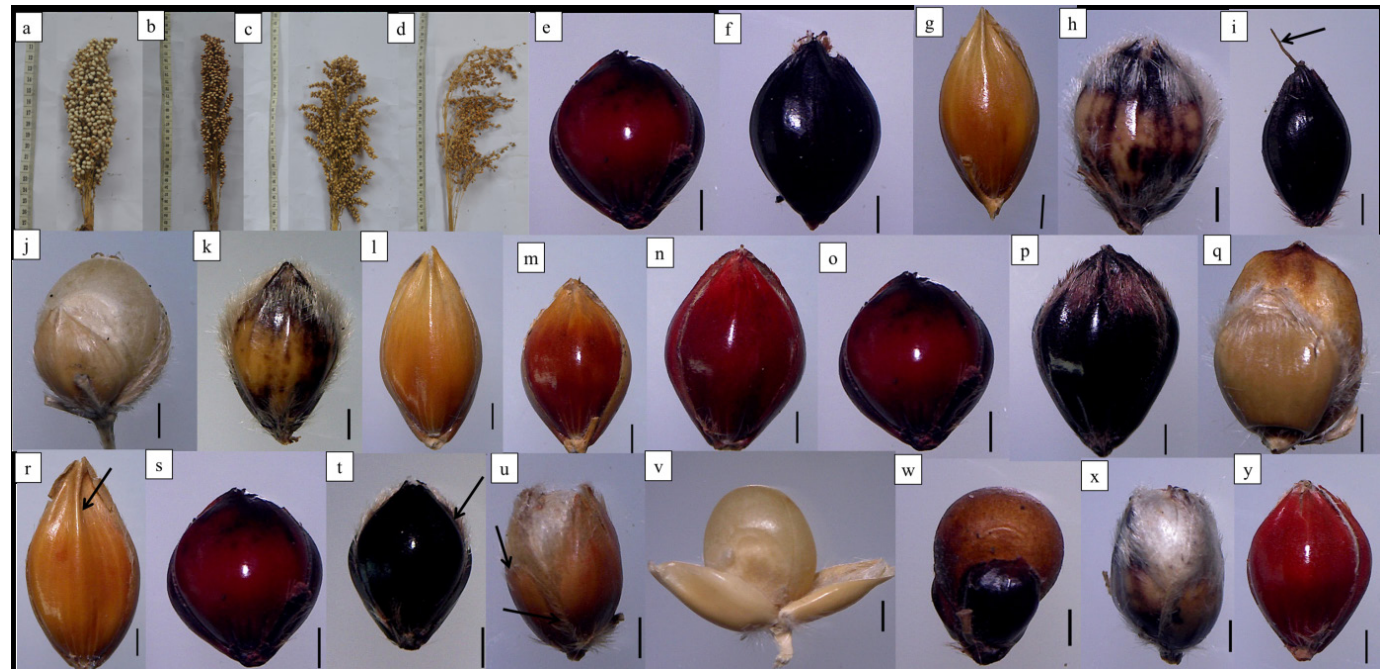

Figure 2. Variations of inflorescence (a-d) and seed with bracts (e-u). Inflorescence compactness: $a$. compact, b. semi-compact, c. semi-open branches, d. open branches. Shape: e. rounded, f. oval, g. ellipse. Presence of awn: h. without awn, i. with awn. Base and apex bracts color: j. goldenrod, k. goldenrod with black pattern, 1. brown, m. base orange-red, apex orange, n. red, o. maroon, p. black. Presence of angle on palea: q. without angle, r. with angle. Presence and location of pubescent pubescent on bractea: s. without pubescent, t. pubescent on edge (arrow), u. pubescent on edge and apex (arrows). Percentage of seed covered by bracts: v. 25\%, w. 50\%, x. 75\%, y. 100\%. e-y: bar scale $=1 \mathrm{~mm}$. 

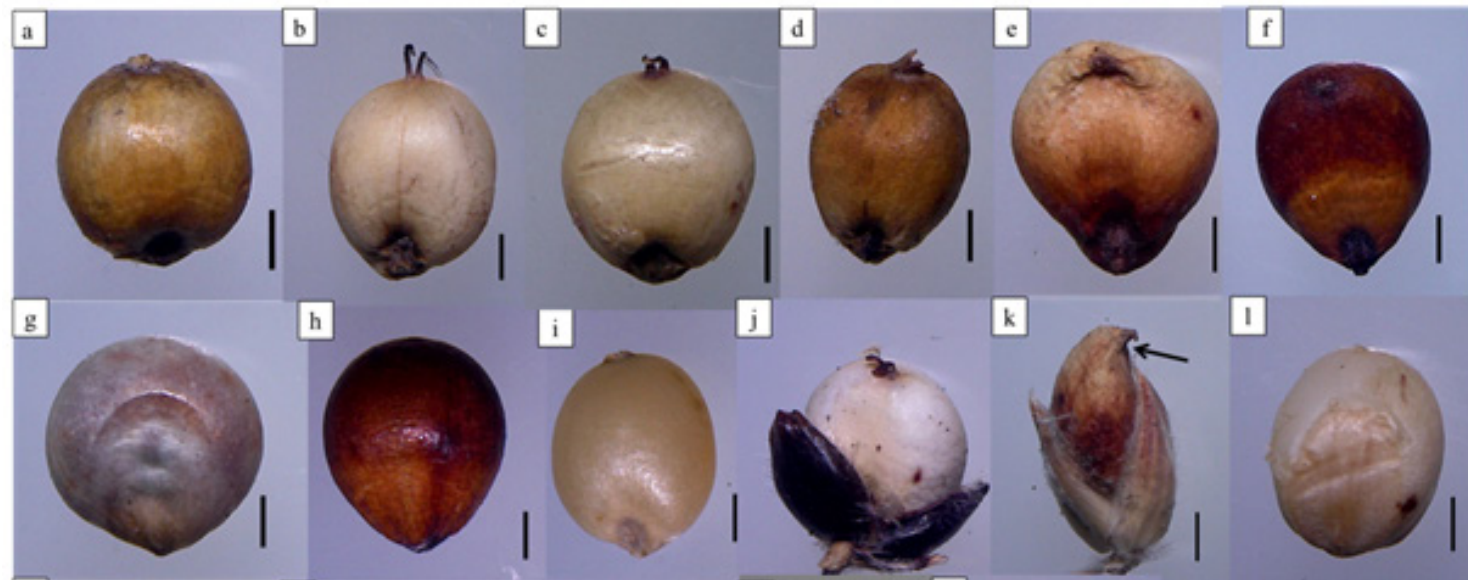

k
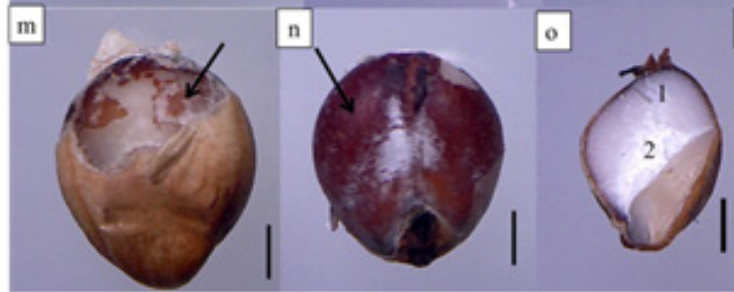

p

q

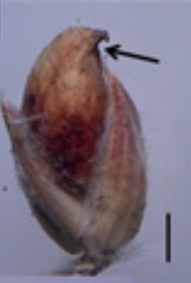

1

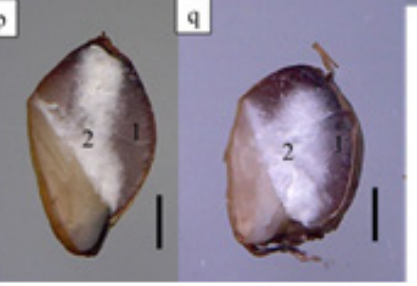

Figure 3. Variations of seed without bracts. Shape: a. round, b. oval. Base and apex color: c. base and apex white, d. base and apex brown, e. base dark brown, apex white brown, f. base brown, apex dark brown, g. base and apex burlywood. Seed lustre: h. dull, i. lustre. Seed dimple: j. without dimple, k. with dimple (arrow). Aleurone presence and color: 1 . without aleurone, $\mathrm{m}$. aleurone with dark brown color (arrow), n. aleurone with sienna color (arrow). Endosperm texture: o. corneus dominant, p. intermediate, q. starch dominant, 1. corneus, 2. starch. Bar scale $=1 \mathrm{~mm}$.

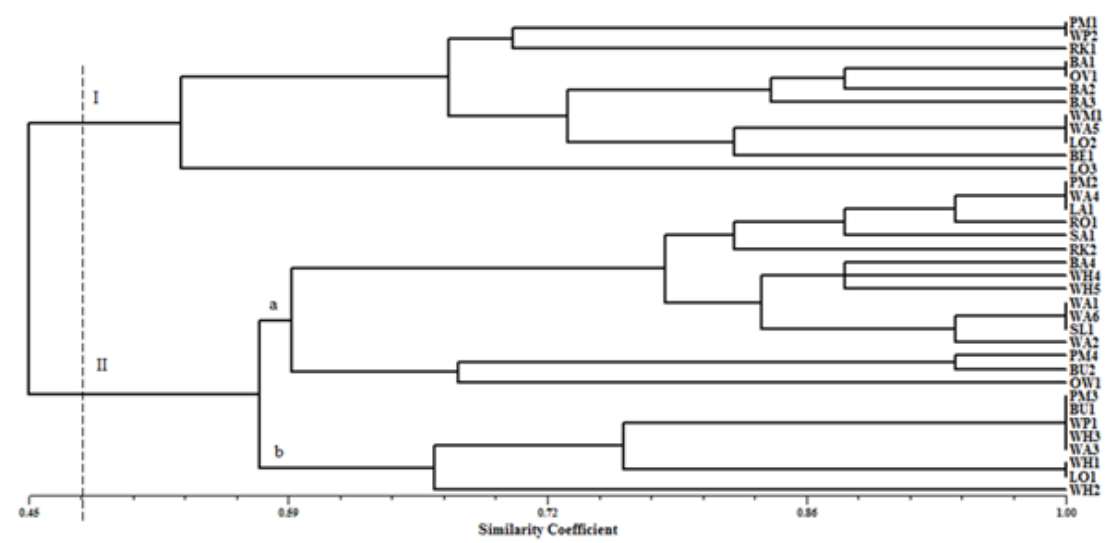

Figure 4. Dendrogram of 36 accessions sorghum based on morphological characters using UPGMA method. $\mathrm{PM}=$ pen mina, $\mathrm{BU}=$ buka, $\mathrm{SA}=$ sain, $\mathrm{BA}=$ batar ainaruk, $\mathrm{WA}=$ watar, $\mathrm{WP}=$ watar pia, $\mathrm{WH}=$ watar holo, $\mathrm{WM}=$ wara blong mera, $\mathrm{BE}=$ batar nae eke, $\mathrm{RK}=$ riang kemie, $\mathrm{LO}=$ lolo, $\mathrm{LA}=$ latung, $\mathrm{RO}=$ rolo, $\mathrm{OV}=$ olo wolo viki, $\mathrm{OW}=$ olo wolo, $\mathrm{SL}=$ sae lewa.

Their seed are covered by bracts ranged from $25-100 \%$, white of base and apex of seed color without bracts, while awn and dimple on seed are absence. Seed lustre was found in two accessions (pen mina 1 and watar pia 2), while the others are dull. There are three groups of similar accessions, i.e. pen mina 1 and watar pia; batar ainaruk 1 and wolo viki 1; watar blong mera 1, watar 5 , and lolo 2.

Group II consisted of accessions with dark brown and sienna aleurone color. All sorghum ac- cessions in this group have oval and ellipse shape of seed with bracts, goldenrod, orange, brown, orange red, and black base and apex of bracts color, also $50-100 \%$ of seed covering by bracts. Awn on seed was found in riang kemie 1, while the seed dimple was found in olo wolo 1 . All sorghum accessions have dull seed with white, white brown, brown, dark brown, and burly wood of base and apex color of seed without bracts. In similarity coefficient of $59 \%$, all sorghum accessions were 
separated into 2 groups based on infloresence compactness. Group a, consisted of 16 accessions with semi-compact and open branches of infloresence, while group $b$ has compact infloresence. In this group, there are four groups of similar accessions with similarity coefficient of $100 \%$, i.e. pen mina 2, watar 4, and latung 1; watar 1, watar 6, and sae lewa; pen mina 3, buka 1, watar pia 1, watar holo 3, and watar 3; watar holo 1 and lolo 1.

Sorghum var. bicolor was grouped into six races, namely bicolor, caudatum, durra, guinea, cafir and nervosum (OGTR, 2017). Based on panicle compactness and spikelet characters, all observed accessions were classified into five races, bicolor, caudatum, guinea, cafir and nervosum. The bicolor race consisted of 17 accessions, pen mina 2, sain 1 , batar ainaruk 4, watar1, watar blong mera 1, batar nai eke, watar holo 4, watar holo 5, watar 2, watar 4, watar 5, watar 6, lolo 2, lolo 3, latung 1, rolo 2, and sae lewa 1. This race is characterized by having seed covered by $100 \%$ of bracts and open branched panicle. Riang kemie 2 accession has ellipse seed. It is grouped into the nervosum race. Riang kemie 1 and olo wolo 1 accessions were grouped into the caudatum race since they have semi-compact and semiopen branched panicle, and their seed are covered by bracts less than $100 \%$. Eight accessions with compact panicle are pen mina 3, open 1, watar pia 2, watar holo 1, watar holo 2, watar holo 3, watar 3, and lolo 1, were grouped into the cafir race. Other accessions with open branched panicle and percentage of seed covered by bracts of $25 \%$ to $75 \%$, pen mina 1, pen mina 4, open 2, batar ainaruk 1, batar ainaruk 2, batar ainaruk 3, watar pia 2 and olo wolo viki 1, were classified into the guinea race.

At the race category, sorghum from East Nusa Tenggara showed high differences in characteristics among all accessions, so that, one more category under race namely forma was formed. Classification on forma level were based on bracts color. Based on the characters, there are five forma within bicolor race and three forma within guinea race. The forma within the bicolor race are brown forma (batar ainaruk 4, watar 1, watar holo 5, watar 2, watar 6, and sae lewa 1), red orange forma (watar holo 4), red forma (watar blong mera 1, watar 5, and lolo 2), maroon forma (lolo 3), and black forma (pen mina 2, sain 1, batar nai eke 5, watar 4, latung 1, and rolo 1). The guinea race consists of three forma, goldenrod forma (pen mina 1, pen mina 4, buka 2, and watar pia 2), brown forma (batar ainaruk 2 and batar ainaruk 3), and goldenrod pattern black forma (batar ainaruk 1 and olo wolo viki 1).

\section{Genetic Diversity of Sorghum Local Cultivar in East Nusa Tenggara}

The genetic diversity of local cultivar sorghum was varied among three islands. The number of observed alleles ranged from 2.35-3.12, while the number of effective alleles is 1.91-2.04. The percentage of polymorphic loci ranged between $76.47-94.12 \%$ and the highest percentage was on Flores island (Table 3). Since Shannon Information Index of local cultivar sorghum ranged between $0.62-0.71(\mathrm{I}<1)$ and Nei's genetic diversity of sorghum in East Nusa Tenggara is $0.37-0.42$, the diversity of sorghum species in East Nusa Tenggara is categorized low. Genetic diversity of species is considered high when Shannon Information Index is more than three, intermediate if $1 \leq \mathrm{I} \leq 3$, and low if $\mathrm{I}<1$ (Odum, 1993). The genetic diversity is also categorized low when Nei's genetic diversity ranged between $0.1-0.4$, intermediate if $0.5 \leq \mathrm{h} \leq 0.7$, and high if $0.8 \leq \mathrm{h} \leq 1$ (Nei, 1987).

Based on the genetic analysis result, genetic diversity between populations $\left(\mathrm{H}_{\mathrm{T}}=0.4203\right)$ is higher than within populations $\left(\mathrm{H}_{\mathrm{S}}=0.3961\right)$ (Table 4). Genetic differentiation between populations value $\left(G_{S T}=0.0575\right)$ indicates that genetic differentiation between sorghum populations is intermediate, but there is a high gene flow among populations $(\mathrm{Nm}=8.2008)$.

The low value of Nei's genetic diversity and Shannon Information Index of sorghum of East Nusa Tenggara is suspected because there are many similar accessions found in different islands. The comparation of genetic diversity of three islands showed that the highest genetic diversity $(\mathrm{h})$ was found in Sumba island $\left(\mathrm{H}_{\mathrm{T}}=0.42\right)$. It is suspected that the observed accessions on Sumba Island have different characteristics one another. In contrast to the Sumba island, there are several similar accessions in Flores island, such as: watar blong mera 1, watar 5 and lolo 2; watar 6 and sae lewa 1; watar holo 3 and watar 3; and watar holo 1 and lolo 1 . As a result, compared to the other island, the Shannon Index value $(\mathrm{I}=0.71)$ of Flores island is the highest, but its genetic diversity $(\mathrm{h}=0.40)$ is lower than Sumba island. Timor island has the lowest genetic diversity $(h=0.37)$ and Shannon information index $(\mathrm{I}=0.62)$. Similar to Flores island, there are two similar accessions in Timor island, pen mina 3 and buka 1. It is not surprising that this island has lower genetic diversity. The small accession number is suspected to influence the genetic diversity of a population. Since small number of accession or species in a population caused the low opportunity for cross pollination, thus, it may decrease the genetic di- 
Ite Morina Yostianti Tnunay et al. / Biosaintifika 11 (1) (2019) 47-54

Table 3. Genetic diversity parameters and polymorphic loci among population in ENT

\begin{tabular}{lccccccc}
\hline Population & $\begin{array}{c}\text { Total } \\
\text { Accession }\end{array}$ & $\mathrm{Na}$ & $\mathrm{Ne}$ & $\mathrm{h}$ & $\mathrm{I}$ & $\mathrm{J}$ & $\mathrm{P}(\%)$ \\
\hline Timor & 11 & 2.35 & 1.92 & 0.37 & 0.62 & 13 & 76.47 \\
Sumba & 3 & 2.12 & 2.04 & 0.42 & 0.65 & 13 & 76.47 \\
Flores & 22 & 3.12 & 1.91 & 0.40 & 0.71 & 16 & 94.12 \\
\hline Average & & 2.53 & 1.96 & 0.40 & 0.66 & 14 & 82.35 \\
\hline
\end{tabular}

$\mathrm{Na}=$ number of observed alleles; $\mathrm{Ne}=$ number of effective alleles; $\mathrm{h}=$ Nei's genetic diversity; $\mathrm{I}=$ Shannon information index, $\mathrm{J}=$ number of locus polymorphic, $\mathrm{P}=$ percentage of locus polymorphic

Table 4. Analysis of the genetic structure of 36 sorghum accessions of ENT

\begin{tabular}{lllll}
\hline Value & $\mathrm{H}_{\mathrm{T}}$ & $\mathrm{H}_{\mathrm{S}}$ & $\mathrm{G}_{\mathrm{ST}}$ & $\mathrm{N}_{\mathrm{m}}$ \\
\hline Average & 0.4203 & 0.3961 & 0.0575 & 8.2008 \\
Standard Deviation & 0.0600 & 0.0537 & &
\end{tabular}

$\mathrm{H}_{\mathrm{T}}=$ genetic diversity between accessions in total populations; $\mathrm{H}_{\mathrm{S}}=$ genetic diversity in population; $\mathrm{G}_{\mathrm{ST}}=$ genetic divergence between populations; $\mathrm{N}_{\mathrm{m}}$ =gene flow

versity of population.

Plant genetic diversity is caused by several factors, i.e., environmental variations, gene flow, and gene mutations. Environmental variety caused not only species diversity but also diversity within species (Muraya et al., 2013). Genetic diversity within populations and between populations also occurred because of gene flow, such as seed or pollen dispersal. Seed and pollen dispersal are influenced by populations distance. When the distance is closer, pollen and seed dispersal will be better. Pollen and seed dispersal can occur through animal feed, fertilizer, animal, and human mobility (Epperson, 2004; Muraya et al., 2013).

Pollen dispersal may trigger cross-pollination in sorghum. Sorghum is a self-pollination plant, but the potential for cross-pollination is high, especially in sorghum with open branched panicle of $30-60 \%$. Even less than $10 \%$, the opportunity to cross-pollination can also occur in compact panicle (Kumar, 2016). Sorghum in East Nusa Tenggara varied in panicle compactness. This variation is suspected causing high genetic diversity within population.

The distance between Timor, Sumba, and Flores islands causes low ability of pollen dispersal, thus, the cross-pollination between sorghum populations is low. Nevertheless, the value of genetic diversity between populations $\left(\mathrm{H}_{\mathrm{T}}=0.4205\right)$ is higher than within population $\left(\mathrm{H}_{\mathrm{S}}=0.3961\right)$. It occurs because gene flow between populations is high $(\mathrm{Nm}=8.2008)$ due to the seed dispersal. According to Zongo et al. (2005) and Muraya et al. (2013), farmers can bring sorghum from one place to another and exchange seeds with nearby areas, so people movement may cause gene flow among populations. The presence of similar accessions in different populations support that gene flow is present between populations located on different island.

Gene mutations in large loci can also affect genetic diversity in a population. Two alleles in a locus will be identical, only if the allele does not mutate from generation to generation, but allele frequency in nature is always diverse or not identical. The diversity of allele frequency will occur when the number of alleles observed is higher than the number of effective alleles (Sinha and Kumaravadivel, 2016; Riupassa et al., 2015). Based on available data, the number of alleles observed is higher than the number of effective alleles, indicating that allele frequency on three islands was varied. According to Kumar et al. (2012), in addition to gene mutation, the diversity of allele frequency in populations can also be affected by evolution, natural selection, and migration.

The characteristic variation, relationship among accessions and genetic diversity of sorghum from East Nusa Tenggara are new data that have not been described in previous studies. Since the genetic diversity of sorghum from this area is low, all information of its morphological variation is very important to be used as basic information for developing sorghum in the future, especially in East Nusa Tenggara where sorghum is an important crop.

\section{CONCLUSION}

Sorghum in East Nusa Tenggara varied in 17 qualitative characters of generative organ, i.e. inflorescence (panicle) compactness, shape 
of seed with bracts, base and apex bracts color, location of pubescent on bracts, angle on palea, percentage of seed covered by bracts; shape, base and apex color of seed without bracts, seed lustre, seed dimple, aleurone color, and endosperm texture. The presence of pubescent on bracts, angle on palea, awn on seeds, seed dimple and aleurone layer were found in some accessions.

All accessions were grouped into one large group with a similarity coefficient of $45 \%$. At the similarity coefficients of $48 \%$, all sorghum accessions were separated into 2 groups based on the presence or absence of aleurone layer. Group I consisted of 12 accessions with no aleurone layer, while group II consisted of 24 accessions with aleurone layer.

The genetic diversity of sorghum of East Nusa Tenggara is low ( $\mathrm{I}=0.62-0.71$ and $\mathrm{h}=0.37$ $0.42)$. The genetic diversity between populations $\left(\mathrm{H}_{\mathrm{T}}=0.4203\right)$ is higher than within populations $\left(\mathrm{H}_{\mathrm{s}}=0.3961\right)$.

\section{ACKNOWLEDGEMENT}

We would like to thank to Indonesia Endowment Fund for Education, Finance Ministry that was funded this research in 2015-2016.

\section{REFERENCES}

[IBPGR and ICRISAT] International Board for Plant Genetic Resources and International Crops Research Institute for the Semi-Arid Tropics. (1993). Descriptors for Sorghum (Sorghum bicolor (L.) Moench). Roma and Patencheru: IBPGR and ICRISAT.

Abdi, A., Bekele, E., Asfaw Z., \& Teshome, A. (2002). Patterns of morphological variation of sorghum (Sorghum bicolor (L.) Moench) landraces in qualitative characters in North Shewa \& South Welo, Ethiopia. Hereditas, 137, 161-172.

Amelework, B., Shimelis, H., Tongoona P., Mark, L. M., \& Mengistu, F. (2016). Genetic diversity of lowland sorghum landraces assessed by morphological and microsatellite markers. Australian J. of Crop Sci., 10, 291-298.

Dahlberg, J., Berenji, J., Sikora, V., \& Latkovic, D. (2011). Assessing sorghum (Sorghum bicolor (L.) Moench) germplasm for new traits: food, fuels and unique uses. Maydica, 56, 85-92.

Deb, U. K., Bantilan, M. C. S., Reddy, B. V. S., Bramel, P. J., \& Rao, N. K. (2004). Impact of Sorghum Cultiars on Genetic Diversity and Yield Stability. Dalam Bantilan MCS, Deb UK, Gowda CLL, Reddy BVS, Obilana AB \& Evenson RE. Sorghum Genetic Enhancement: Research Process, Dissemination and Impacts. Patancheru: International Crops Research Institute for the SemiArid Tropics.

Epperson, B. K. (2004). Multilocus estimation of ge- netic structure within populations. Theor. Popul. Biol., 65, 227-237.

Etuk, E.B., Ifeduba, A.V., Okata, U. E., Chiaka, I., Okoli, Ifeanyi, C., Okeudo, N. J., Esonu B. O., Udedibie, A. B., \& Moreki, J. C. (2012). Composition and feeding value of sorghum for livestock \& poultry: a review. J. of Animal Sci. Adv., $2,410-524$.

Gerrano, A. S., Labuschagne, M. T., van Biljon A., \& Shargie, N. G. (2014). Genetic diversity assessment in sorghum accessions using qualitative morphological \& amplified fragment length polymorphism markers. Sci. Agri., 71, 394-401.

Kimura, M. \& Crow, J. (1964). The number of alleles that can be maintained in a finite population. Genet., 49, 725-738.

Kumar, A.A., Reddy, B.V.S., Ramaiah, B., Sahrawat, K.L., Wolfgang, H.P. (2012). Genetic variability and character association for grain iron and zinc contents in sorghum germplasm accessions and commercial cultivars. Eur. J. Plant. Sci. Biotechnol. 6(1):66-70

Kumar, A.A. (2016). Botany, Taxonomy and Breeding. In Rakshit, S. \& Wang, Y. H. (eds.), The Sorghum Genome, Compendium of Plant Genomes. Switzerland: Springer International Publishing. DOI 10.1007/978-3-319-47789-3_2

Morojele, M. E. \& Mbewe, D. N. M. (2015). Genetic diversity of common beans as determined using morphological markers. Asian J. of Agri. \& Biol., 3, 2-7.

Muraya, M. M., de Villiers, S., Parzies, H. K., Mutegi, E., Sagnard, F., Kanyenji, B. M., Kiambi, D., \& Geiger, H. H. (2013). Genetic structure and diversity of wild sorghum populations (Sorghum spp.) from different eco-geographical regions of Kenya. Theor. Appl. Genet., 123, 571-583.

Nei, M. (1987). Molecular Evolutionary Genetics. New York: Columbia University Press.

Odum, E. P. (1993). Dasar-Dasar Ekologi, Ed ke-3. Yogyakarta: Gajah Mada University Press.

Riupassa, P. A., Chikmawati, T., Miftahudin, \& Suharsono. (2015). The molecular diversity-based ISSR of Durio tanjungpurensis originating from West Kalimantan, Indonesia. Makara J. Sci., 19, 27-36.

Rolf, F. J. (2001). NTSYSpc Numerical Taxonomy and Multivariate Analysis System Version 2.02 User Guide. Stony Brook: State University of New York.

Sinha, S. \& Kumaravadivel, N. (2016). Understanding genetic diversity of sorghum using quantitative traits. Scientifica, 1-8.

Sirappa, M. P. (2003). Prospek pengembangan sorgum di Indonesia. Jurnal Litbang Pertanian, 22, 133140.

Yeh, F. C., Yang, R., \& Boyle, T. (1999). Popgene Version 1.31 Microsoft Window-Based Freeware for Population Genetic Analysis, Quick User Guide. Alberta: University of Alberta and Centre for International Forestry Research.

Zongo, J. D., Gouyon, P. H., Sarr, A., \& Sandmeier, M. (2005). Genetic diversity and phylogenic relations among Sahelian sorghum accessions. Genet. Res. Crop Evol., 52, 869-878. 